\title{
38
}

\section{Ten Theses on the Subject of Biology and Politics: Conceptual, Methodological, and Biopolitical Considerations}

\author{
Samantha Frost
}

\section{Introduction}

Recent findings in the life sciences trace how social and material elements of our environments shape human growth and development. In the fields of endocrinology, developmental systems biology, immunology, epigenetics, and neuroscience, among others, researchers are finding that humans are not simply embedded in their lived environments but that they compose and recompose themselves biologically - at molecular and cellular levels-in response to them (Cole 2014; Keller 2010, 2015; Robinson et al. 2005; Slavich and Cole 2013). Interestingly, the dynamics between embodied self and lived environment that scientists have begun to trace have been anticipated over the past decades in efforts by feminist theorists and social and political theorists to explain the phenomenon of subject formation - the processes through which a human organism comes to be recognized as and to see him- or herself as a specific person within a historically and geographically particular community (Foucault 1982). Although the modes of knowledge production mobilized by life scientists and social and political theorists are distinct, the logics and constituting forces of the movements between environment and self they analyze resonate quite profoundly.

The aim of this chapter is to develop a set of concepts and methodological principles that researchers might draw on as they try to elucidate the processes

S. Frost $(\bowtie)$

University of Illinois at Urbana-Champaign, Champaign, IL, USA 
by which the engagement of humans with their social worlds, material environments, and historical cultures results in the formation of a self in subjective, corporeal, as well as biological dimensions. The idea here is not finally to reconcile findings in the life sciences with theories promulgated by critics of social and political life along the lines proposed, for instance, by Edward O. Wilson (1999). Rather, the idea is to forge a conceptual language and rules for analysis that will enable scholars to negotiate productively the commonalities, similarities, and tensions in converging accounts of how the social norms, lived environments, and power relations through which people develop a sense of self are bound up with the processes through which biological organisms compose and recompose themselves over time.

In this chapter, then, I will begin with a sketch of a conceptual map of the points of provocative contact or resonance between life science and political theoretical understandings of the social and material processes through which people develop. This map will situate-conceptually and logically - the subsequent unfolding of ten theses. In providing such a map and set of theses, the chapter will not present a survey of the history of these scientific and theoretical developments or of the burgeoning literatures on this topic - a project far too unwieldy for the task at hand (Meloni 2016; Meloni and Testa 2014; Pickersgill et al. 2013). Rather, the chapter will provide a conceptual—and in many ways ontological—foundation and related guidelines for studying humans conceived as biocultural creatures.

\section{The Map}

The theoretical insights that anticipate and help us make sense of the scientific findings about biocultural humans are many; here, I draw brief attention, in particular, to two. The first is the insight, articulated well by Judith Butler, that the subject does not pre-exist the linguistic and cultural forms through which it represents and symbolizes itself (1992). When social and political theorists make such a claim, they mean that an individual does not become a person and then, subsequently, use language or enjoy culture. Rather, individuals become persons only through using some form of language and being acculturated and acknowledged in some form of community with symbolic means of self-representation. This first insight tells us, then, that symbolic and representational forms, as manifest through language, cultural practices, institutional imperatives, economic, social, and political activities, and forms of self-understanding, together shape behavior, identity, and desire, making us who we are. 
The second insight to which I draw attention is the relatively recent move by a range of theorists to refuse the posture of human exceptionalism (Agamben 2003; Braidotti 2013; Grosz 2011; Wolfe 2010). This refusal takes aim at the notion that humans are possessed of some quality-rational, willful, linguistic, moral, cultural - that exempts them from the forms of conditioning, dependency, and vulnerability that attend living life as a creature. Through analyzing and refusing what Agamben (2003) calls "the anthropological machine" or the desperate (and ultimately futile) effort definitively to distinguish humans from animals and from the material world of their support, theorists call into question moral, political, and economic ideas that derive human prerogative or privilege from humans' putatively exceptional status. The corollary of this refusal of human exceptionalism is an insistence on foregrounding humans' animality, embodiedness, fleshiness, and materiality, their embeddedness in very particular social and material environments, as well as their dependence upon various technologies (Alaimo 2010; Chen 2012; Grosz 2005, 2011; Haraway 2012; Hird 2009; Ingold 2000; Stiegler 1998). This posture of refusal, combined with the insight that subjects are constituted, paves the way for political theorists and cultural analysts to conceptualize subject formation not just in terms of language, culture, and politics but also in terms of embodiedness, creatureliness, and the material and technological elements of the environment that make living possible.

As theorists have elaborated these theoretical insights together, they have crept closer and closer to living flesh, seeing social norms, political imperatives, institutional organization, and symbolic forms of self-understanding infuse the embodied subject to an extent that theorists talk of the embodiment of norms, the materialization of power, or the corporealization of culture. These kinds of analyses show us, for example, that gender and race are not merely socially informed modes of understanding that can be selfconsciously transformed through better information, but rather are solicitous and coercive modes of social address and cultural and political practice that shape social expectation, perception, encounter, and relation so thoroughly that "gender" and "race" as socially and politically significant markers appear to originate in the body as natural phenomena (Alcoff 2005; Butler 1992; Lee 2014; Weheliye 2014). Yet, as Birke (2000), Roberts (2007), Frost (2014), and Wilson (2015), among others, have noted, in spite of manifold and theoretically rich efforts to trace how the forces constituting subjects make us inhabit, move in, and experience our bodies in particular ways, many social and political theorists have been wary of exploring the extent to which the biological processes and biological matter of the body might be shaped, formed, or deformed by the vagaries of social and political life. 
This wariness about including biological processes in accounts of subject formation has many causes, not least of which is the ongoing effort of social and political theorists to challenge the use of biology as an index of social and political status - and the corollary use of sex, race, and ability as the hinge upon which political dignity and freedom rest. Elizabeth Wilson (2015) argues that as theorists have pushed against a figuration of the biological body as a phenomenon that could determine the contours of social and political life, they have produced as a conceptual accretion of their refusal a figuration of biology as "a passive substrate...that culture animates" (31). Which is to say that, constrained by a sense of political danger, many social and political theorists have cleaved to the terms of social constructivism to an extent that, with the exception of the administration of pharmaceuticals or surgical intervention, they have been reluctant to entertain the possibility that biology conceived as the life processes of an organism might be shaped by or be a factor in social and political phenomena.

It is only quite recently that social and political theorists have begun to explore whether the concepts of "embodiment," "incorporation," and "materialization" that are intended to capture the processes through which bodies are shaped by social and cultural factors might also have specifically biological dimensions (Fausto-Sterling 2004, 2005, 2008, 2012; Grosz 2005, 2011; Lee 2014; Saldanha 2009; Warin et al. 2015; Wilson 2004, 2015). In this emerging genre of scholarship, biology is conceived not as a stable something that subsists doggedly beneath its varied social and political guises but rather as a collection of dynamic processes that are sensitive and responsive to the series of habitats through which humans sustain themselves - and thus as a contributing element in the formation of humans as persons.

Intriguingly, the effort by such theorists to consider biological processes in non-reductive, creatively variable terms is being met by developments in various fields of the life sciences - especially epigenetics as it is pursued through many disciplines (Cacioppo et al. 2013; Cole 2014). In a review of contemporary studies, George Slavich and Stephen Cole (2013) note a trend among scientific researchers in which the "deeply engrained...perception of biological stability and impermeability" is being challenged (331). They recount that according to findings in fields such as neuroscience, immunology, and endocrinology, the molecular and cellular scale composition and work of the body is increasingly seen as a function of "the physical and social environments we inhabit," with "people's subjective perception of their social environment" having more transformative effect than "the 'objective' features" (331). Evelyn Fox Keller (2015) similarly explains that the genome is increasingly recast as an "exquisitely sensitive and reactive system" (10) that responds to "the con- 
stantly changing signals it receives from its environment" (25). So, as scientists explore how social and material factors shape the composition and recomposition of biological bodies, they are abandoning the notion that biological bodies are relatively closed off from the world with their inner workings impervious to and protected from the environment (Landecker and Panofsky 2013; Lock 2013; Meloni 2014; Niewohner 2011; Rose 2013). Instead, genes, proteins, cells, and organisms are viewed as open to the environment, as constantly changing in response to the environment (Jablonka and Lamb 2005; Lewontin 2002; Rabinow and Caduff 2006; Robinson et al. 2005; Slavich and Cole 2013). And stupendously, the environment here is construed not simply as chemical or material but also as social, representational, symbolic, and imagined, including such phenomena as family dynamics, workplace inequalities, perceptions of social inequality, anticipated loss of a relationship, and the daily micro and macro politics of living in a racialized polity (McEwen 2012; Muscatell et al. 2016; Robinson et al. 2005; Romens et al. 2015; Rose 2013; Slavich 2016; Slavich and Cole 2013; Thayer and Kuzawa 2011). I cannot emphasize this last point enough, since it is here that findings in the life sciences are beginning conceptually to meet insights in social and political theory: through tracing the particulars of how felt psychosocial experiences evoke various biochemical shifts that affect gene transcription and reverse transcription-and thereby the making of the proteins and such that enable our bodies to function-scientists are beginning to assay the ways that experiences of social interaction, and the anticipation and imagination of social interaction, have a constituting effect upon the biological body.

Before going any further, I want to clarify that the openness of bodies to their environments identified by scientists is not just an expansion of the factors to which bodies respond, that is, an increase in the number of factors that provoke transformations in the biological functioning of bodies. More, as Guthman and Mansfield (2013) explain, this openness to the environment is one through which bodies are "active in [their] own remaking" — an openness through which environmental factors provoke transformations in the composition and recomposition of bodies, in the ways they are produced and reproduced on a daily basis as well as across life times and generations (497). I emphasize this point because, in some areas of the social sciences, it is fashionable to try to capture the relation between environment and body through invoking the notion of interaction, as if human subjects are a product of a kind of pushand-pull encounter between biological and cultural factors. Under such a rubric, the aim of studying biology along with culture is to sort out which factors are biological, which cultural, and how they come to some productive 
balance (e.g. Alford et al. 2005; Kandler et al. 2012; and contra Beckwith and Morris 2008; Charney 2008, 2012; Charney and English 2012).

There are a couple of problems with this interactionist framework to draw out here. The first is that the idea of interaction presumes a coherence and integrity to the living subject that it brings to an encounter with a habitat, as if the subject were not ensconced in a habitat all along (Keller 2010; Latour 2004; Oyama 2000). That is, it presumes a subject effectively unencumbered by a habitat who, with a fixed genome and fully grown - with a settled "constitution" as Fowler and Schrieber (2008) might put it—stumbles into an environment to which it proceeds to respond. The second is that, as noted above, in presuming such an unencumbered extra-environmental subject, its encounter with an environment is conceived as provoking a response that changes how the body works, but has no effect on how or with what the body is made (Guthman and Mansfield 2013).

The problem with the conceptual framework of interaction is similar to the problem identified in cultural and political theory of positing the existence and features of a subject anterior to its action in a field or context. In working around this problem, theorists point out that social ideas, cultural norms, and disciplinary imperatives are not just representational (i.e. painting a picture of a thing that is there), but are also constitutive (i.e. actively involved in the formation of the subject through inciting and delimiting the identifications, attentions, and desires that make the subject intelligible to and able to navigate in its social and political situation).

We have to do a similar correction when critically engaging the interactionist framework. As Lappé and Landecker (2015) explain, "time and context have come (in)to the genome" such that the genome is now conceived as having a varied temporal horizon or a "life span" within which changes in environmental provocations are registered at the level of chromatin (152). These temporally and contextually sensitive dimensions of the genome mean that biological processes do not pre-exist the environments in which they proceed and persist but are constituted through responsiveness to those environments. Thus, Landecker (2016) says, it is not simply the case that the body responds to the environment but rather that the environment provokes the making and remaking of "the responsive body" (95). If we keep this correction in mind, we can see that, in contradistinction to the interactionist framework, biology is not a substance antecedent to environment and culture whose existential priority is the limiting condition for cultural and environmental effects. Rather, cultural and environmental forces and phenomena together constitute the enabling and provoking conditions for biological bodies to compose, 
decompose, and recompose themselves in ways that reflect and anticipate those conditions.

What is remarkable about this moment in social and political theory and the life sciences is that in both genres of research, scholars endeavor to articulate and trace the processes and mechanisms by which social and material environments shape our development and growth as human persons, as acculturated subjects. Findings produced in the contemporary life sciences could give social and political theorists the means to explore how ideas, culture, and the vagaries of material environments shape living matter; how disciplinary norms, cultural imperatives, and sinuous forms of power shape biological processes at the same time as they constitute subjects. And the work that theorists and cultural critics have been doing for the past decades giving spatial and temporal depth and texture to the experiences of power, culture, and identity could serve as a resource for scientists as they endeavor to trace how, as McEwen (2012) puts it, the "social gets under the skin." In other words, this moment represents the possibility for informative, productive intellectual exchange across research domains where heretofore there has not been much.

One of the things that hobbles such admittedly difficult interchange is the lack of a common conceptual vocabulary and shared methodological principles for guiding research across zones of familiarity (Callard and Fitzgerald 2015; Pickersgill et al. 2013). Providing such a conceptual vocabulary and sketching some such principles is the aim of the remainder of this chapter. And again, the point of this project is not to facilitate a final reconciliation of the sciences, social sciences, and humanities but rather to provide something of a path, a way in, for researchers interested in developing more expansive accounts of human development and subject formation.

To facilitate the use of this chapter as a waypoint on an interdisciplinary trip, I will use a "thesis" format rather than presenting a continuous narrative argument. For those looking for a fuller, more textured experience, many of the points articulated here appear in long-winded form in my recent book (Frost 2016). What I do here is refine and distill from that project discrete claims or theses that can serve as discrete points of reference even as, at the same time, each is a moment in the unfolding of the logic of a larger idea. Being schematic in this way enables me to be concise in laying out an idea and then to explain the theoretical and political significance of the claims along with the logic that binds those points into a coherent conceptual map for investigating humans in their world. In fact, it is the logic of the concepts that underlies many of the prescriptive and proscriptive claims that I make along the way. 
As a schema, the theses start minutely and somewhat abstractly, and then they build step by step a concept of humans that demands different, and differently detailed, figures of movement and interchange between body and environment. Each thesis is substantively distinct; at the same time, each is logically linked to the ones that precede and follow. I will elaborate the thinking that undergirds each thesis as I go. Note that theses 1 through 7 make substantive (one might want to say ontological) claims, building a theoretical picture of humans as biocultural creatures. Theses 8 through 10 address the possibilities and cautions for research presented within a framework in which humans are conceived as biocultural creatures. The earlier theses have conceptual and methodological implications, the later, methodological and political.

\section{The Ten Theses}

Thesis 1 All living organisms, including humans, are porous. This thesis captures the openness of living creatures to the material and social environments that culture them and enable them to grow. The porosity, here, is meant in both the metaphorical sense in which human subjects are constituted in and through linguistic and cultural forms, and in the literal sense that living organisms, including human subjects, are constituted and compose themselves with and through their engagement with their habitats (Alaimo 2010; Fausto-Sterling 2012; Guthman and Mansfield 2013, Hoffmeyer 2008; Landecker 2011; Lock 2013; Niewohner 2011). What is rejected in the stipulation of this thesis are the suppositions, mentioned above, that the bodies of living organisms are in some aspect closed to their environments, that living organisms are distinct from their habitats and thereby merely interact with them, and that human subjects precede and thus merely enter into and move in the field of their action.

At the center of this thesis is the commonplace scientific insight that the membranes of each and every cell in a living creature are permeable in such a manner that there is an influx and efflux, a prolific traffic, of biochemicals into and out of them at every moment. This traffic is more than a mere passive diffusion of biochemicals. It is provoked and made possible by the myriad proteins and biomolecules made by organisms in response to stability or change in their social and material environments as well as to their perception or imagination of stability or change in their social and material environments. There is a continuous movement of substances across the porous boundaries of cells, across the porous boundaries of bodies-and it is this 
movement and traffic that underpins the processes of living and of subject formation.

Thesis 2 What distinguishes the inside of a porous human creature from the outside that is its social and material habitat is the specific concentration and concatenation of activities and processes composing and decomposing it. This thesis answers the vexing possibility that the porosity of living organisms-and all the traffic that is implied by cell membrane permeability-makes it impossible to specify a distinction between the inside and the outside of a cell or a body. That is, it addresses the concern that porosity-whether meant metaphorically or literally_-results in a kind of environmental reductionism. It is indeed the case that, because there is a constant traffic of biochemicals across cell membranes, we cannot say that the distinction between the inside and the outside of a cell, between the inside and the outside of a body, is a substantive one, a matter of substance. Evan Thompson (2007) marks this insight when he observes that "because its material composition is constantly renewed," the identity of an organism "cannot be based on the constancy of matter" (150). But, clearly, cell membranes are boundaries, and they serve an important boundary function, which is to say that cell membrane porosity is not equivalent to a complete lack of boundary. The question is: what is the boundary function of porous cell membranes?

Jesper Hoffmeyer (2008) notes that the traffic of biochemicals back and forth across porous cell membranes creates "a basic asymmetry between an inside and an outside, making the membrane a potential interface structure" (34). These asymmetries or cross-membrane differentials in biochemical concentrations and electrochemical charges provoke and make possible the protein-rebuilding, chemical transforming, moving-stuff-around activities inside cells that constitute the manifold processes of living. Or to put the point differently, the cellular activities that constitute living are impossible without the precise changes in biochemical concentration and electrochemical charges made possible by cross-membrane traffic. Because of the dependence of cellular activities upon cross-membrane traffic, we can say that rather than being a substantive distinction, the distinction between the inside and the outside of a cell, between the inside and outside of a body, should be seen as one characterized by the specific forms of activity made possible by the permeable boundary. In construing the distinction between the inside and the outside in terms of activity, we can retain a claim about the ontological singularity of each organism even as we acknowledge that each is likely symbiotic with and embedded among many others and all manner of constituent forces and elements. 
Thesis 3 A living organism is, at any one moment, a temporally particular configuration of processes of composing and decomposing. This thesis elaborates the idea that the distinction between the inside and the outside of a living organism is a distinction in activity. When biochemicals flow into and out of cells across permeable cell membranes, their changing concentrations provoke a myriad of cellular activities. These cellular activities build proteins and other biomolecules that make possible an increase or decrease in that crossmembrane flow, a change that in turn provokes more cellular activities. Cells are precisely responsive to the cross-membrane traffic of biochemicals, and their responses take the form of creating the conditions for further traffic and response-composing, decomposing, and recomposing molecules that together enhance or diminish further traffic of biochemicals into and out of cells. Because the processes of composing and decomposing provoked by cross-membrane traffic are the condition for further processes of composing and decomposing - that are the condition of further processes of composing and decomposing - we should avoid thinking about living bodies as staid matter, as stolid, static, and given. For similar reasons, we should not think about what crosses cell membranes or what is generated in response as merely a deposit, a sedimentation, or an imprint. The responses to the cross-membrane traffic of biomolecules are as much activities of decomposing and recomposing as they are activities of composing.

This thesis holds before us the notion that what we refer to as the biological body is not pure or fixed but rather is constantly building and rebuilding itself. The constant cross-membrane traffic and related cellular activity mean that the form that living human creatures live and experience as ourselves in any given moment is one instantiation of the processes of composing, decomposing, and recomposing that are continuously under way.

Thesis 4 All organisms, including humans, are biocultural. This thesis blends the first three to provide a figuration of humans that captures how bodies compose and recompose themselves in response to provocations of the traffic of biochemicals across cell membranes. The amalgam term "biocultural" is used here to evoke the insight, as articulated by Elizabeth Wilson, that "All worlds are alloyed; no object is purebred" (2015: 29). In other words, it is used to reference the insight that there is no aspect of a living organism that is not cultured, that persists in its activities of composition and decomposition of its own accord rather than through its interrelation, absorption, and transformation with other substances, organisms, and creatures (Fausto-Sterling 2012; Haraway 2012; Jablonka and Lamb 2005; Lewontin 2002; Lock 2013; Niewohner 2011). 
Such bio-culturing means that bones, cells, DNA, genes-or whatever putatively "really on the inside" bio-things we can imagine- exist and persist only through the processes of composing and decomposing made possible by the traffic of stuff into and out of cells, across the permeable boundaries of the body. In other words, the "bio-" of human organisms exists and persists only because stuff on the outside, in the environment, traverses to the inside-and back. Such bio-culturing also means that the perception of and identification with norms in historically and culturally specific places, their internalization and experience as a sense of self, and experiences of relating and working in accordance with those norms as they manifest in the social and material organization of life are in the turgid mix of processes through which living human organisms compose and recompose themselves as they live and grow.

We can list four general groups of phenomena that are integral to and are the conditions for the composing and decomposing of living human subjects:

(a) Matter from the outside of the body enters the body, and biochemicals inside exit, and both directional movements support or transform the activities of composing and decomposing. We can think here of chemicals, minerals, microbes, gases, nutrients, and toxins (Guthman and Mansfield 2015; Landecker 2011).

(b) The shifting organization and disposition of matter and energy, such as light, sound, space, heat, vibration, gravity, and radioactivity, enters into and impinges upon the modes, speeds, and manners of activity by which organisms compose, decompose and recompose (Faber Taylor and Kuo 2006; Fitzgerald et al. 2016).

(c) Humans' perception of, experience in, and active engagement with their social and material worlds generate intellectual, emotional, psychological, and behavioral responses that involve, in part, the circulation of hormones, steroids, neurochemicals, and other biochemicals that shape and reshape cellular activities of composing and decomposing (Cole 2009; Fitzgerald et al. 2016; Kuzawa and Sweet 2009; McEwen 2012; Mendenhall et al. n.d.; Muscatell et al. 2016; Romens et al. 2015; Saldanha 2009; Thayer and Kuzawa 2015; Wilson 2011). We can think here of social interactions, labor activity, cultural practices, eating patterns, hygienic habits, exercise regimes, institutional involvements, military service, arts training, transit and travel, access to health care, exposure to violence, and so on.

(d) Human's anticipatory, imaginative, and "inner-worldly" engagements with their social and material worlds generate intellectual, emotional, and 
behavioral responses that involve, in part, the circulation of hormones, steroids, neurochemicals, and other biochemicals that shape and reshape cellular activities of composing and decomposing (Davis and Morris 2007; McEwen 2012; Muscatell et al. 2016; Slavich and Cole 2013). We can think here of expectations about upcoming events, insights into inequality, affective suasion, transitory identifications, memory, guilt, reading, aesthetic inspiration, and other things that are a mix of this group and the one prior.

The point of this thesis is that matter, energy, sensuous and social perception, and varieties of memory and imagination all together make possible, provoke, redirect, and delimit a living human subject's processes of composing and decomposing. Because these factors coincide in variously productive, disruptive, and intensifying ways to condition and make possible a living human subject's processes of composing and decomposing, we must think of humans as not just biological and not just cultural but instead as biocultural.

Thesis 5 The habitats that culture living organisms, including humans, are biocultural. This thesis is an extension and logical corollary of the prior thesis. The environment in which humans live and come into being as subjects is not merely the background for action, nor only an object of action, but also, ineluctably, a compositional factor in human subjects' composing, decomposing, and recomposing activities. The sense in which I am using the term "habitat," then, draws on the notion of "milieu" developed by Jakob von Uexkull (2010) and Georges Canguilhem (2008) according to whom a milieu is not merely an object-filled space in which a creature moves but a meaningful field constitutive of life and sense of self for the organisms who grow and live within it.

Social and political theorists tend to get half of the point of this thesis when we think in terms of the ways that aesthetics, cultural practices, norms, and institutions shape modes of identity and subject formation. And life scientists tend to get another half when thinking in terms of the ways that nutrients and toxins shape development and growth within lifetimes and across generations. But we have just seen that the factors that condition and make possible the processes of composing and decomposing are mineral, chemical, energetic, spatial, organic, microbial, social, perceptual, normative, aesthetic, and imaginative. Since each and every one of these factors together-synergistically and discordantly — make possible, redirect, and recalibrate a living human subject's processes of composing and decomposing, the habitats that culture humans qua biocultural creatures are best conceived not as just one aspect (social/symbolic/representational) nor as just one kind (material/chemical/ 
microbial). All of them co-occur as the biocultural habitats that culture humans.

Thesis 6 The responses of biocultural creatures to bio-culturing are noncontemporaneous with their current habitats. This thesis points to a time lag between environmental provocations and the activities of responsive composing and recomposing. This time lag trips up any easy turn to behaviorism or environmental reductionism in thinking about how humans as biocultural creatures live in and engage with their worlds. As noted above, a living body responds to the constant inflow and outflow of matter, energy, and percepts by adjusting the forms and the frequencies of its activities of composing and decomposing. When a living body responds to its habitat by adjusting its activities of composing and recomposing, those adjustments "set the template for the future" (Landecker 2016: 95) in the sense that they prepare that living body to respond well to similar future habitats. A body's adjustment of the activities of composing and recomposing is anticipatory (Meloni and Testa 2014), a carrying forward of current responses in preparation for future responses (Frost 2014, 2016; Oyama 2000). These adjustments are variably durable, having short-term, medium-term, and long-term effects upon the activities of composing and decomposing in individual lifetimes as well as in the composing and decomposing activities of subsequent generations (Champagne 2011; Guerrero-Bosgana and Skinner 2009; West-Eberhard 2005). Because responsive adjustments endure in these ways, they affect subsequent responses of a living body to subsequent inflows and outflows of matter, energy, and percepts. These anticipatory adjustments mean that, at any point in time, the array of a living body's possible responses to its immediate habitat is not wholly contemporaneous with that habitat. A body's responses to inflows and outflows of matter, energy, and percepts are the material and energetic trace of that body's or of previous generations of bodies' past responses to past habitats. Because any future habitat inevitably is different from in the sense that it does not coincide exactly with the one that provoked the preparatory responsiveness, a creature's biology is noncontemporaneous with its habitat.

Thesis 7 In the noncontemporaneity of organisms vis-à-vis their habitats lies the distinction of living organisms, including human subjects, from the habitats that culture them. This thesis refines the second thesis concerning the distinction between the inside and the outside of the body and reinforces the rejection of behaviorism and environmental reductionism seen in the sixth thesis. By adding the temporality of the processes of living to the account of the ontological singularity of each organism, this thesis heads off the concern that the selective porosity of living organisms and their responsiveness to their habitats entail that living creatures be conceived as merely responses to habi- 
tats, smears emerging from the background environment. The noncontemporaneity of a living body's responsiveness to its habitat means that a living organism is not reducible to its current habitat. Because responsive adjustments to the activities of composing and decomposing are carried forward through time to shape subsequent responses to subsequent habitats, a living organism's capacity to respond to a contemporary habitat is an effect of its past responses to past habitats. Meloni and Testa (2014) explain this noncontemporaneity in remarking that the body of a biocultural creature "is at once inhabited by the traces of its past and seeded with traces of its future" (15). From within the perspective that construes organisms as biocultural, then, the fleshy "itness" of living bodies - what we experience as the physical form and substance of the embodied self-is a product of that anticipatory carrying forward of past responses. Which is to say that the existence of living bodies as discrete ontological phenomena is an effect of their noncontemporaneity with their habitats.

Thesis 8 Biocultural habitats, and the biocultural creatures cultured in them, are multiscalar, both temporally and spatially. This thesis highlights the idea that the conditions for the activities of composing and decomposing within biocultural creatures occur at the fine molecular and cellular scale all the way up through the macro spatial scales of global political economy and global climate change, at temporal scales reaching from fractions of a second through lifetimes, generations, and eons (Oyama et al. 2001; Fujimura 2005). I pose this as one of the theses because the deployment of restrictive temporal and spatial scales in research on humans as biocultural creatures can have a distorting effect on findings. As Shostak and Moinester (2015) observe, the huge spatial and temporal variability in the way that researchers conceptualize the environment generates "regimes of perceptibility' in which particular aspects of the environment become more or less visible" (195). So, for example, Landecker (2011) argues that "the experimental formalization of food" in epigenetics research can lead to food "stand[ing] in for the environment in the dyad of 'gene-environment interactions" (168). Similarly, Darling et al. (2016) contend that because "biospecimen collection" is seen as "a marker of robust science," researchers often use the body as a "surrogate" for the environment (55) with the effect that they "reduce social processes to bodies" (57). In both cases, a narrow focus on a specific spatial scale obscures from analytic view the broader social and political milieux in which food is produced and rendered available or in which psychological and biological stressors are generated and experienced.

Below, I outline three interrelated problems already anticipated and observed in some of the related literature when the temporal and spatial mul- 
tiscalarity is ignored, when biocultural creatures and biocultural habitats are construed very narrowly and within a limited time frame.

One problem is a kind of environmental determinism in which the spatial and temporal multiscalarity of biocultural habitats is narrowed sharply with the effect that members of particular neighborhood or section of a city might be judged as producing and reproducing, by themselves, malignant social relations, persistent poverty, endemic violence, or toxicological health crises (Duster 2006a; Mansfield 2012; Rose and Abi-Rached 2013). In focusing on how patterns of behavior, illness, or trauma "become ingrained within a specific population" - geographically or demographically defined-researchers ignore myriad spatial and temporal scales of social and material environments, generalizing claims across rich and variegated communities and obscuring the historical and structural forces that constitute the community as such (Meloni and Testa 2014: 17). Some of the scales rendered imperceptible in such monoscalar research approaches can be personal and interpersonal, such as intergenerational family and kinship networks, community organizations, policing practices, educational institutions, population migration, and participation in popular and sub-cultures. Others scales can be structural, impersonal, and political, such as patterns of commercial and residential zoning, labor market transformations, national and governmental ideologies, wars, and so forth. The point here is that at all of these scales together, biocultural habitats create the conditions for diverse, cross-textured forms of subjectivity at the same time that they contribute to regionally and locally persistent patterns of poverty or violence. To ignore the temporal and spatial multiscalarity of biocultural habitats is to risk homogenizing a population and misconstruing social and political phenomena, often in ways that perpetuate ideologically saturated assumptions about class, race, ethnicity, gender, sexuality, and national origin (Duster 2006a; Mansfield 2012).

Another problem with ignoring the temporal and spatial multiscalarity of biocultural creatures and biocultural habitats is the mobilization of a neoliberal conception of the individual according to which individuals are held to be responsible for anticipating and ameliorating the health and developmental effects of toxins or poverty or stress by managing their homes or workspaces or illnesses by themselves (Darling et al. 2016; Mansfield 2012; Meloni and Testa 2014; Rose 2007). To focus on the individual without considering the many scales of the social and material environments that shape their lives is to individualize and moralize problems like pollution, economic transformation, and political violence that are properly conceived as collective problems demanding collective, political solutions (Brown 2005). To proceed by granting the full spatial breadth and temporal depth of biocultural habitats 
and the humans cultured in them is to put oneself in a position to discern patterns and trends in subject formation, behavior, culture, environment, and political economy-and possibilities for transformation-that otherwise might be missed or overlooked.

And a third problem that follows from ignoring the temporal and spatial multiscalarity of biocultural creatures and biocultural habitats is the figuration of the maternal body - or the uterus - as the environment in which babies grow (Daniels 1997, 2006; Martin 1991; Richardson 2015; Richardson et al. 2014). This spatial and temporal narrowing ignores both men's and women's exposures to reproductive, developmental, and teratogenic toxins over their lifetimes. It also obscures the intimate, social, political, and economic contexts that shape how women live when they are pregnant or raising children. Such a spatial and temporal narrowing renders women singularly responsible for fetal and child health, often in ways that are clinically incomplete as well as morally, socially, and legally punitive.

In attending to the spatial and temporal multiscalarity of biocultural creatures and biocultural habitats, researchers are better prepared to detect and account for these problematic kinds of scale slippage. Rachel Lee (2014) argues that if we can hold before our analytic attention these combined or transecting scales, we will be able to discern those instances in which research that includes biocultural factors might rely on the "affective, psychic importance" of extant racial, gender, and sexual categories and their "materialization in legal, clinical, commercial and civil social contexts" (54). We will also, she claims, be more readily alert to the creation of "micro-scale risk factors as new markers of difference" (57). Indeed, Lee speculates that as the notion that humans are biocultural creatures diffuses through different research and policy fields, it is quite possible that "race—as a synecdoche for exploited, expendable bodies and bodily parts/habits-must make room for finer articulations of how disabled, diseased, or virally positive, impoverished, imprisoned, or otherwise debilitated classes are constituted as the new 'aliens'” (57).

In pointing to the need to attend to the multiple spatial and temporal scales at which bio-culturing occurs, this thesis nevertheless does not demand that everything and all time frames should be put in the front and center of analysis-a paralyzing and likely impossible task. As a range of scholars have suggested, distinctions and priorities must be made so as to be able to engage in study, but the parsing of those lines and the circumscription of analysis should be carefully considered, explained, and revised if they delimit rather than facilitate understanding (Barad 2007; Connolly 2013; Latour 2004, 2013; Oyama et al. 2001). 
Thesis 9 Research on humans conceived as biocultural creatures must take into consideration, if not into full account, the combined material, spatial, social, and representational dimensions of the processes of bio-culturing. This thesis is an insistent reminder of what it means to say that humans are biocultural creatures. According to the prior theses, living human subjects are composed and recomposed, formed and reformed, through the material, chemical, nutritive, toxic, gaseous, spatial, and microbial constituents of living processes as well as the desires, norms, ideas, principles, identifications, disciplines, and forms of resistance that attend collective social and political life. To study subject formation or the development of persons, then, we need to account for all the biocultural constituents formative of living human subjects and to trace the characteristics of those biocultural formations.

So, for instance, to study the embodiment of norms or the circulation of affects might require going further in one's analysis than elucidating the ways that social norms, ideological expectations, political upsets, and institutional inequalities give a dispositional tenor to the experience of being a subject. It might also require that one explore how affects' varied durability and mutability in social and political subjects reflect and provoke hormonal, steroidal, neurochemical, immune, and other transformations that induce a subject's body to compose and recompose in ways that are experienced as habitual anger, periodic stress, a spate of irritability, or a spell of what José Muñoz (2006) called "feeling brown." Alternatively, as Elizabeth Wilson (2011) has argued, the study of depression might include not only biochemical imbalances, pharmaceutical prescriptions, dietary patterns, and personal trauma but also social and familial bonds, the experience of health, employment opportunities, institutional inequalities, displacement, cultural norms, political and economic shifts, and cultural or collective trauma.

This thesis, then, pushes researchers to consider the fullness and multidimensionality of biocultural creatureliness and biocultural habitats, even in projects that have a primary orientation in cultural critique or scientific investigation.

Thesis 10 The ontological distinctness and historical singularity of each human conceived as a biocultural creature can only be understood through considering how the social and political differentiation of people into groups creates patterns in the biocultural habitats in which each individual grows and lives. This thesis is a response to the possibility that the idea that humans are biocultural creatures will be taken as license to champion the irreducible biological singularity of each individual. Within such a scenario, the fact that biological processes track the singular history of each living individual's series of habitats is taken to mean that demographic group categories, like race and ethnicity, can be tabled 
as analytically irrelevant (Hibbing 2013). However, as Rajagopalan and Fujimura (2012) point out, while the prospect that each person's epigenomic health profile is "unique" can be "potentially democratizing" in medical fields that historically have apportioned diagnosis and care according to broad political racial categories, research that consequently ignores socially and politically potent demographic categories does not take adequate account of the fact that "differences in disease incidence among different race and ethnic groups" correlate "with socioeconomic disparities that exist between different race and ethnic groups in the U.S." $(661,659)$. To track how social and political life shapes biological processes is to have to conceive of race, for instance, as not merely a way of looking at or telling stories about particular people (a form of representation) but also as a patterned set of political, cultural, and economic institutions and practices that differentiate groups and structure the places and the means by which people live their lives (Haywood 2013; Weheliye 2014). Because social and material worlds are constituent conditions for the living persistence of biocultural creatures, and because those social and material worlds are organized in accordance with complex political formations like race, class, and gender, the biological processes of composing, decomposing, and recomposing are ineluctably, if variably, constituted through the experience of living as members of historically and geographically particular groups (Duster 2006b; Fujimura et al. 2014; Hancock 2013; Saldanha 2009).

This dimension of the tenth thesis may seem tricky to navigate because thinking about demographic groups in conjunction with biology is fraught with awareness of various political histories of racial biologism and eugenics (Esposito 2008, 2012; Fujimura and Rajagopalan 2011; Mbembe 2003; Meloni 2016; Meloni et al. 2016; Montoya 2007, 2011; Roberts 2011; Schiebinger 1993). However, in consonance with some of the theses outlined here, there are a number of scholars venturing to recalibrate the temporal and spatial frameworks within which race is imagined and analyzed. Such temporal and spatial recalibrations allow us to account for the constituted character of race as well as for the ways that it is experienced phenomenologically and lived bioculturally. For such scholars, race emerges as a lived reality through the social and geopolitical relations and institutions that are organized in accordance with symbolic and representational modes of differentiating groups (Fausto-Sterling 2008; Lee 2014; Kuzawa and Sweet 2009; Saldanha 2009, Thayer and Kuzawa 2011; Wright 2015).

In such analyses, the variegated spatial scale compels us to take into account the specificities of racial formation at the level of identity, norms, and interpersonal relations as well as in the geographies and cultures of institutions, neighborhoods, cities, regions, nations, and digital communities. What is per- 
tinent here ranges from the micro-aggressions of everyday life to gross patterns of political, economic, legal, and cultural distinction and separation. The variegated temporal scale compels us to take into account not only the historical specificity of the forms of symbolization and representation that mobilize and reference differentiation but also the means through which those histories are carried partially forward and oftentimes mixed in various politi$\mathrm{cal}$ and economic institutions and in a range of cultural and legal practices. Because these approaches foreground the complex spatial and temporal dimensions of racial formation and racialization, they provide a means to understand the embodiment of race as a dynamic process that has enduring although not intransigent effects on the processes that constitute living for humans conceived as biocultural creatures.

What is particularly striking is these analyses that recalibrate the spatial and temporal dimensions of race is the way in which what we know as "race" is doubled in the sense that it is neither just cultural nor just biological but rather both—or biocultural as the concept is developed through this chapter. So, in one facet of analysis, race consists in an astonishingly complex variety of symbolic, social, material, and oftentimes violent forms of differentiation. In another corner of analysis are the effects that these forms of differentiation have on the circulation of stress hormones and steroids, the sensitivity of inflammatory and immunitary processes, the regularity of sleep patterns, the digestion and metabolism of nutrients, and vulnerabilities to injury, sickness, and depression, all of which in turn affect how people live with and among one another, shaping them as social and political subjects (Mendenhall et al. n.d.; Thayer 2014; Thayer and Kuzawa 2015). From within this doubled perspective, race as social and political differentiation and organization produces biocultural habitats that culture biocultural creatures in ways affected by that differentiation and organization. To deploy the terms of Troy Duster's (2006a, b) argument, racialized biocultural subjects are produced as such through living in racially striated biocultural habitats.

One of the dangers in pointing out this kind of doubling is that the social and political marks of representation might be taken as a proxy, for example, for the kinds of biological traces of stress that are induced by features of the social and material environments organized in keeping with those representational forms and norms. I am thinking here of the forms of racialized medicine that generalize health predicaments via racial categories (Duster 2005, 2015; Fujimura 2015; Fullwiley 2008; Inda 2014; Montoya 2007; Roberts 2011; Tallbear 2013). To mitigate this slippage from "the biocultural formation of racialized subjects" to "race as a cause or marker of disease," we need to attend (again) to the multiple scales and varied topologies and temporalities of biocul- 
tural habitats. We need to keep in mind that simply being racialized in a racially differentiated biocultural habitat is not determinative for a demographically delimited form of good or ill health. Racial forms of differentiation are crosscut by class, gender, and myriad other micro and macro dimensions of biocultural habitats, not only in the material organization of life in the form of work, diet, shelter, toxins, medical care, and green space but also in the patterns of ideas, icons, friendships, and kinship relations that provide inspiration, consolation, desolation, and hope. Furthermore, the evental, periodic, habitual, or chronic persistence of these biocultural factors, the timespan of life within which they provoke each biocultural subject, their concurrence, synchronicity, or asynchronicity with each other all have an effect on how a biocultural creature develops and persists, in sickness or in health. The complexity of biocultural factors involved in composing, decomposing, and recomposing biocultural creatures means that even when human subjects live together in similar biocultural habitats, they will not necessarily have similar lives or similar selves. Perhaps another way to state the point of this thesis is that we cannot appreciate or apprehend how living subjects' biological processes are responsive to their biocultural habitats without taking into account what those biocultural habitats are.

PAUSE.

With nods and winks to Karl Marx's Theses on Feuerbach (1978), I am often asked what the 11 th thesis might be. It is not logically necessary. But an 11 th thesis would likely petition scholars to formulate their questions and present their findings in ways that enhance rather than detract from the conditions for people's political or collective self-determination.

Acknowledgments For the opportunity to present and discuss these ideas, I am grateful to the participants of the Unit for Criticism Faculty Fellows Symposium, Unit for Criticism and Interpretive Theory at the University of Illinois, UrbanaChampaign; the Kent Summer School in Critical Theory, the University of Kent; and the Coloquio Internacional "Neo-materialismo: La vida humana y su lugar en el cosmos," Universidad Nacional de Córdoba. Many thanks also to Chantal Nadeau, Des Fitzgerald, and Maurizio Meloni for their thoughtful engagement.

\section{References}

Agamben, Giorgio. 2003. The Open: Man and Animal. Trans. Kevin Atell. Stanford, CA: Stanford University Press.

Alaimo, Stacy. 2010. Bodily Natures: Science, Environment, and the Material Self. Bloomington, IN: Indiana University Press. 
Alcoff, Linda. 2005. Visible Identities: Race, Gender, and the Self. New York: Oxford University Press.

Alford, John R., Carolyn Funk, and John R. Hibbing. 2005. Are Political Orientations Genetically Transmitted? American Political Science Review 99 (2, May): $153-167$.

Barad, Karen. 2007. Meeting the Universe Halfway: Quantum Physics and the Entanglement of Matter and Meaning. Durham, NC: Duke University Press.

Beckwith, Jon, and Corey Morris. 2008. Twin Studies of Political Behavior: Untenable Assumptions? Perspectives on Politics 6 (4): 785-791.

Birke, Lynda. 2000. Feminism and the Biological Body. New Brunswick, NJ: Rutgers University Press.

Braidotti, Rosi. 2013. The Posthuman. Malden, MA: Polity.

Brown, Wendy. 2005. Edgework: Critical Essays on Knowledge and Politics. Princeton, NJ: Princeton University Press.

Butler, Judith. 1992. Contingent Foundations: Feminisms and the Question of 'Postmodernism'. In Feminists Theorize the Political, ed. Judith Butler and Joan Scott, 3-21. New York: Routledge.

Cacioppo, John T., Stephanie Cacioppo, and Steven W. Cole. 2013. Social Neuroscience and Social Genomics: The Emergence of Multi-Level Integrative Analyses. International Journal of Psychological Research 6: 1-6.

Callard, Felicity, and Des Fitzgerald. 2015. Rethinking Interdisciplinarity across the Social Sciences and Neurosciences. New York, NY: Palgrave Macmillan.

Canguilhem, Georges. 2008. "The Living and its Milieu” in Knowledge of Life trans.

In Stefanos Geroulanos and Daniela Ginsberg, ed. Paola Marrati and Todd Meyers. New York, NY: Fordham University Press.

Champagne, Frances A. 2011. Maternal Imprints and the Origins of Variation. Hormones and Behavior 60: 4-11.

Charney, Evan. 2012. Behavior Genetics and Post Genomics. Behavioral and Brain Sciences 35 (5): 331-358.

- 2008. Genes and Ideologies. Perspectives on Politics 6 (2): 321-328.

Charney, Evan, and William English. 2012. Candidate Genes and Political Behavior. American Political Science Review 106 (1): 1-34.

Chen, Mel. 2012. Animacies: Biopolitics, Racial Mattering, and Queer Affect. Durham, NC: Duke University Press.

Cole, Steven W. 2009. Social Regulation of Human Gene Expression. Current Directions in Psychological Science 18 (3): 132-137.

—. 2014. Human Social Genomics. PLoS Genetics 10 (8): e1004601. doi:10.1371/journal.pgen.1004601.

Connolly, William. 2013. The 'New Materialism' and the Fragility of Things. Millennium - Journal of International Studies 41 (3): 399-412.

Daniels, Cynthia. 1997. Between Fathers and Fetuses: The Social Construction of Male Reproduction and the Politics of Fetal Harm. SIGNS: Journal of Women in Culture and Society 22 (3): 579-616. 
2006. Exposing Men: The Science and Politics of Male Reproduction. New York: Oxford University Press.

Darling, Katherine Weatherford, Sara L. Ackerman, Robert H. Hiatt, Sandra Soo-Jin Lee, and Janet K. Shim. 2016. Enacting the Molecular Imperative: How Geneenvironment Interaction Research Links Bodies and Environments in the Postgenomic Age. Social Science \& Medicine 155: 51-60.

Davis, Lennard J., and David B. Morris. 2007. Biocultures Manifesto. New Literary History 38 (3): 411-418.

Duster, Troy. 2005. Race and Reification in Science. Science 307: 1050-1051.

2006a. Behavioral Genetics and Explanations of the Link between Crime,

Violence, and Race. In Wrestling with Behavioral Genetics: Science, Ethics, and Public Conversation, ed. E. Parens, A.R. Chapman, and N. Press, 150-175. Baltimore: Johns Hopkins University Press.

2006b. Lessons from History: Why Race and Ethnicity have Place a Major Role in Biomedical Research. Journal of Law, Medicine, and Ethics 34 (3): 487-496.

- 2015. A Post-genomic Surprise: The Molecular Reinscription of Race in Science, Law and Medicine. The British Journal of Sociology 66 (1): 1-27.

Esposito, Roberto. 2008. Bios: Biopolitics and Philosophy. Minneapolis, MN: University of Minnesota Press.

- 2012. Third Person: Politics of Life and Philosophy of the Impersonal. Malden, MA: Polity.

Faber Taylor, A., and F.E. Kuo. 2006. Is Contact with Nature Important for Healthy Child Development: State of the Evidence. In Children and their Environments, ed. C. Spencer and M. Blades, 124-140. Cambridge: Cambridge University Press. Fausto-Sterling, Anne. 2004. Refashioning Race: DNA and the Politics of Health Care. Differences: A Journal of Feminist Cultural Studies 15 (3): 1-37.

- 2005. The Bare Bones of Sex: Part I-Sex and Gender. SIGNS: Journal of Women in Culture and Society 30 (2): 1491-1527.

- 2008. The Bare Bones of Race. Social Studies of Science 38 (5): 657-694.

—. 2012. Sex/Gender: Biology in a Social World. New York: Routledge.

Fitzgerald, Des, Nikolas Rose, and Ilnia Singh. 2016. Living Well in the Neuropolis. The Sociological Review Monographs 64 (1): 221-237.

Foucault, Michel. 1982. The Subject and Power. Critical Inquiry 8 (4): 777-795.

Fowler, James H., and Darren Schrieber. 2008. Biology, Politics, and the Emerging Science of Human Nature. Science 322: 912-914.

Frost, Samantha. 2014. Reconsidering the Turn to Biology in Feminist Theory. Feminist Theory 15 (3): 307-326.

2016. Biocultural Creatures: Towards a New Theory of the Human. Durham, NC: Duke University Press.

Fujimura, Joan. 2005. Postgenomic Futures: Translations across the Machine-biology Border in Systems Biology. New Genetics and Society 24 (2): 195-225.

- 2015. A Different Kind of Association between Socio-histories and Health. The British Journal of Sociology 66 (1): 58-67. 
Fujimura, Joan H., and Ramya Rajagopalan. 2011. Different Differences: The Use of 'Genetic Ancestry' Versus Race in Biomedical Human Genetic Research. Social Studies of Science 41 (1, Feb.): 5-30.

Fujimura, Joan H., Deborah A. Bolnick, Ramya Rajagopalan, Jay S. Kaufman, Richard C. Lewontin, Troy Duster, Pilar Ossorio, and Jonathan Marks. 2014. Clines Without Classes: How to Make Sense of Human Variation. Sociological Theory 32 (3): 208-227.

Fullwiley, Duana. 2008. The Biologistical Construction of Race: 'Admixture' Technology and the New Genetic Medicine. Social Studies of Science 38 (5.) (October): 695-735.

Grosz, Elizabeth. 2005. The Nick of Time: Politics, Evolution, and the Untimely. Durham, NC: Duke University Press.

- 2011. Becoming Undone: Darwinian Reflections on Life, Politics and Art. Durham, NC: Duke University Press.

Guerrero-Bosgana, Carlos M., and Michael K. Skinner. 2009. Epigenetics Transgenerational Effects of Endocrine Disruptors on Male Reproduction. Seminar on Reproductive Medicine 27 (5): 403-408.

Guthman, Julie, and Becky Mansfield. 2013. The Implications of Environmental

Epigenetics: A New Direction for Geographic Inquiry on Health, Space, and Nature-Society Relations. Progress in Human Geography 37 (4): 486-504.

- 2015. Plastic People. Aeon, 23 February.

Hancock, Ange-Marie. 2013. Neurobiology, Intersectionality, and Politics: Paradigm Warriors in Arms. Perspectives on Politics 11 (2): 504-507.

Haraway, Donna. 2012. When Species Meet. Minneapolis, MN: University of Minnesota Press.

Haywood, Clarissa Rile. 2013. How Americans Make Race: Stories, Institutions, Spaces. New York, NY: Cambridge University Press.

Hird, Myra J. 2009. The Origins of Sociable Life: Evolution After Science Studies. New York, NY: Palgrave Macmillan.

Hibbing, John. 2013. Ten Misconceptions Concerning Neurobiology and Politics. Perspectives on Politics 11 (2): 475-489.

Hoffmeyer, Jesper. 2008. Biosemiosis: An Examination into the Signs of Life and the Life of Signs. Scranton, PA: University of Scranton Press.

Inda, Jonathan Xavier. 2014. Racial Prescriptions: Pharmaceuticals, Difference, and the Politics of Life. Burlington, VT: Ashgate.

Ingold, Tim. 2000. The Perception of the Environment: Essays on Livelihood, Dwelling, and Skill. New York, NY: Routledge.

Jablonka, Eva, and Marion Lamb. 2005. Evolution in Four Dimensions: Genetic, Epigenetic, Behavioral, and Symbolic Variation in the History of Life. Cambridge, MA: MIT Press.

Kandler, Christian, Wiebke Bleidorn, and Rainer Riemann. 2012. Left or Right? Sources of Political Orientation: The Roles of Genetic Factors, Cultural Transmission, Assortative Mating, and Personality. Journal of Personality and Social Psychology 102 (3): 633-645. 
Keller, Evelyn Fox. 2010. The Mirage of a Space between Nature and Nurture. Durham, NC: Duke University Press.

. 2015. The Postgenomic Genome. In Postgenomics: Perspectives on Biology after the Genome, ed. Sarah Richardson and Hallam Stevens. Durham, NC: Duke University Press.

Kuzawa, Christopher W., and Elizabeth Sweet. 2009. Epigenetics and the Embodiment of Race: Developmental Origins of US Racial Disparities in Cardiovascular Health. American Journal of Human Biology 21 (1): 2-15.

Landecker, Hannah. 2011. Food as Exposure: Nutritional Epigenetics and the New Metabolism. Biosocieties 6 (2): 167-194.

Landecker, Hannah, and Aaron Panofsky. 2013. From Social Structure to Gene Regulation, and Back: A Critical Introduction to Environmental Epigenetics for Sociology. Annual Review of Sociology 39: 333-357.

Landecker, Hannah. 2016. The Social as Signal in the Body of Chromatin. The Sociological Review Monographs 64 (1): 79-99.

Lappé, Martine, and Hannah Landecker. 2015. How the Genome Got a Life Span. New Genetics and Society 34 (2): 152-176.

Latour, Bruno. 2004. Politics of Nature: How to Bring the Sciences into Democracy. Cambridge, MA: Harvard University Press.

- 2013. An Inquiry into Modes of Existence: An Anthropology of the Moderns. Trans. Catherine Porter. Cambridge, MA: Harvard University Press.

Lee, Rachel C. 2014. The Exquisite Corpse of Asian America: Biopolitics, Biosociality, and Posthuman Ecologies. New York, NY: New York University Press.

Lewontin, Richard. 2002. The Triple Helix: Gene, Organism, and Environment. Cambridge, MA: Harvard University Press.

Lock, Margaret. 2013. The Epigenome and Nature/Nurture Reunification: A Challenge for Anthropology. Medical Anthropology 32 (4): 291-308.

Mansfield, Becky. 2012. Gendered Biopolitics of Public Health: Regulation and Discipline in Seafood Consumption Advisories. Environment and Planning D: Society and Space 30: 588-602.

Martin, Emily. 1991. The Egg and the Sperm: How Science has Constructed a Romance Based on Stereotypical Male-Female Roles. SIGNS: Journal of Women in Culture and Society 16 (3): 485-501.

Marx, Karl. 1978. Theses on Feuerbach. In The Marx/Engels Reader, ed. Robert C. Tucker, 2nd ed. New York, NY: W. W. Norton.

Mbembe, Achille. 2003. Necropolitics. Public Culture 15 (1): 11-40.

McEwen, Bruce S. 2012. Brain on Stress: How the Social Environment Gets Under the Skin. Proceedings of the National Academy of Science 109: 17180-17185.

Meloni, Maurizio. 2014. Biology without Biologism: Social Theory in a Post-genomic Age. Sociology 48 (4): 731-746.

- 2016. Political Biology: Science and Social Values in Human Heredity from Eugenics to Epigenetics. New York, NY: Palgrave Macmillan. 
Meloni, Maurizio, and Giuseppe Testa. 2014. Scrutinizing the Epigenetics Revolution. Biosocieties 9 (4): 431-446.

Meloni, Maurizio, Simon Williams, and Paul Martin. 2016. The Biosocial: Sociological Themes and Issues. The Sociological Review Monographs 64 (1): 7-25. Mendenhall, Ruby, Lori Henderson, Barbara Scott, Lisa Butler, Kedir N. Turi, Lashuna Mallett, Bobbie Wren, et al. n.d. Involving Urban Single Low-Income African American Mothers in Genomic Research: Giving Voice To How Place Matters in Health Disparities and Prevention Strategies. Unpublished paper.

Montoya, Michael J. 2007. Bioethnic Conscription: Genes, Race, and Mexicana/o Ethnicity in Diabetes Research. Cultural Anthropology 22 (1): 94-128.

- 2011. Making the Mexican Diabetic: Race, Science, and the Genetics of Inequality. Berkeley, CA: University of California Press.

Muñoz, José Esteban. 2006. Feeling Brown, Feeling Down: Latina Affect, the Performativity of Race, and the Depressive Position. SIGNS: Journal of Women in Culture and Society 31 (3): 675-688.

Muscatell, Keely A., Katarina Dedovic, George M. Slavich, Michael R. Jarcho, Elizabeth C. Breen, Julienne E. Bower, Michael R. Irwin, and Naomi I. Eisenberger. 2016. Neural Mechanisms Linking Social Status and Inflammatory Responses to Social Stress. Social Cognitive and Affective Neuroscience 11 (6): 915-922.

Niewohner, Jorg. 2011. Epigenetics: Embedded Bodies and the Molecularisation of Biography and Milieu. BioSocieties 6 (3): 279-298.

Oyama, Susan. 2000. Evolution's Eye: A System's View of the Biology-Culture Divide. Durham, NC: Duke University Press.

Oyama, Susan, Paul E. Griffiths, and Russell D. Gray, eds. 2001. Cycles of Contingency: Developmental Systems and Evolution. Cambridge, MA: MIT Press.

Pickersgill, Martyn, Jorg Niewöhner, Ruth Müller, Paul Martin, and Sarah Cunningham-Burley. 2013. Mapping the New Molecular Landscape: Social Dimensions of Epigenetics. New Genetics and Society 32 (4): 429-447.

Rabinow, Paul, and Carlo Caduff. 2006. Life-After Canguilhem. Theory, Culture and Society 23 (2/3): 329-331.

Rajagopalan, Ramya, and Joan H. Fujimura. 2012. Will Personalized Medicine Challenge or Reify Categories of Race and Ethnicity? Virtual Mentor: American Medical Association Journal of Ethics 14 (8.) (August): 657-663.

Richardson, Sarah S. 2015. Maternal Bodies in the Postgenomic Order: Gender and the Explanatory Landscape of Epigenetics. In Postgenomics: Perspectives on Biology after the Genome, ed. Sarah S. Richardson and Hallam Stevens, 210-231. Durham, NC: Duke University Press.

Richardson, Sarah, Cynthia Daniels, Matthew W. Gillman, Rebecca Kukla, Christopher Kuzawa, and Janet Rich-Edwards. 2014. Don't Blame the Mothers. Nature 512: 131-132.

Roberts, Celia. 2007. Messengers of Sex: Hormones, Biomedicine, and Feminism. Cambridge: Cambridge University Press. 
Roberts, Dorothy. 2011. Fatal Invention: How Science, Politics and Big Business Recreate Race in the Twenty-First Century. New York: New Press.

Robinson, Gene, Christina M. Grozinger, and Charles W. Whitfield. 2005. Sociogenomics: Social Life in Molecular Terms. Nature 6: 257-271.

Romens, Sarah E., Jennifer McDonald, John Svaren, and Seth D. Pollak. 2015. Associations between Early Life Stress and Gene Methylation in Children. Child Development 86 (1): 303-309.

Rose, Nikolas. 2007. The Politics of Life Itself: Biomedicine, Power, and Subjectivity in the Twenty-First Century. Princeton, NJ: Princeton University Press.

- 2013. The Human Sciences in a Biological Age. Theory, Culture and Society 30 (1): 3-34.

Rose, Nikolas, and Joelle Abi-Rached. 2013. Neuro: The New Brain Sciences and the Management of the Mind. Princeton, NJ: Princeton University Press.

Saldanha, Arun. 2009. Reontologising Race: The Machinic Geography of Phenotype. Environment and Planning D: Society and Space 24 (1): 9-24.

Schiebinger, Londa. 1993. Nature's Body: Gender in the Making of Modern Science. Boston: Beacon Press.

Shostak, Sara, and Margot Moinester. 2015. The Missing Piece of the Puzzle? Measuring the Environment in the Postgenomic Moment. In Postgenomics: Perspectives on Biology after the Genome, ed. Sarah Richardson and Hallam Stevens, 192-209. Durham, NC: Duke University Press.

Slavich, George M. 2016. Life Stress and Health: A Review of Conceptual Issues and Recent Findings. Teaching of Psychology 43 (4): 346-355.

Slavich, George M., and Steven W. Cole. 2013. The Emerging Field of Human Social Genomics. Clinical Psychological Science 1 (3): 331-348.

Stiegler, Bernard. 1998. Technics and Time. Vol. I. The Fault of Epimetheus. Trans. Richard Beardsworth. Stanford, CA: Stanford University Press.

Tallbear, Kim. 2013. Native American DNA: Tribal Belonging and the False Promise of Genetic Science. Minneapolis, MN: University of Minnesota Press.

Thayer, Zaneta M. 2014. The Vitamin D Hypothesis Revisited: Race-Based Disparities in Birth Outcomes in the United States and Ultraviolet Light Availability. American Journal of Epidemiology 179 (8): 947-955.

Thayer, Zaneta M., and Christopher W. Kuzawa. 2015. Ethnic Discrimination Predicts Poor Self-rated Health and Cortisol in Pregnancy: Insights from New Zealand. Social Science and Medicine 128: 36-42.

2011. Biological Memories of Past Environments: Epigenetic Pathways to Health Disparities. Epigenetics 6 (7): 798-803.

Thompson, Evan. 2007. Mind in Life: Biology, Phenomenology, and the Sciences of the Mind. Cambridge, MA: Belknap Press of Harvard University Press.

von Uexkull, Jakob. 2010. A Foray Into the Worlds of Animals and Humans. Trans. Joseph D. O’Neil. Minneapolis, MN: University of Minnesota Press.

Warin, Megan, Vivienne Moore, Michael Davies, and Stanley Ulijaszek. 2015. Epigenetics and Obesity: The Reproduction of Habitus through Intracellular and 
Social Environments. Body and Society 22: 53-78. doi:10.1177/1357034X1 15590485 .

Weheliye, Alexander G. 2014. Habeas Viscus: Racializing Assemblages, Biopolitics, and Black Feminist Theories of the Human. Durham, NC: Duke University Press.

West-Eberhard, Mary Jane. 2005. Developmental Plasticity and the Origin of Species

Differences. Proceedings of the National Academy of Sciences 2: 6543-6549.

Wilson, Edward O. 1999. Consilience: The Unity of Knowledge. New York, NY: Vintage.

Wilson, Elizabeth A. 2004. Psychosomatic: Feminism and the Neurological Body. Durham, NC: Duke University Press.

Wilson, Elizabeth A. 2011. Neurological Entanglements: The Case of Paediatric

Depressions, SSRIs, and Suicidal Ideation. Subjectivity 4 (3): 277-297.

. 2015. Gut Feminism. Durham, NC: Duke University Press.

Wolfe, Cary. 2010. What is Posthumanism? Minneapolis, MN: University of Minnesota Press.

Wright, Michelle M. 2015. Physics of Blackness: Beyond the Middle Passage Epistemology.

Minneapolis, MN: University of Minnesota Press.

Samantha Frost is a professor in the Department of Political Science, the Department of Gender and Women's Studies, and the Unit for Criticism and Interpretive Theory at the University of Illinois, Urbana-Champaign, where she is also presently the IPRH-Mellon faculty fellow directing the "Bio-Humanities" initiative funded by the Andrew W Mellon Foundation and housed by the Illinois Program for Research in the Humanities. Her recent publications include Biocultural Creatures: Towards a New Theory of the Human (Duke University Press, 2016), an argument she is currently extending to develop an account of biocultural subjectivity.

Open Access This chapter is licensed under the terms of the Creative Commons Attribution 4.0 International License (http://creativecommons.org/licenses/by/4.0/), which permits use, sharing, adaptation, distribution and reproduction in any medium or format, as long as you give appropriate credit to the original author(s) and the source, provide a link to the Creative Commons license and indicate if changes were made.

The images or other third party material in this chapter are included in the chapter's Creative Commons license, unless indicated otherwise in a credit line to the material. If material is not included in the chapter's Creative Commons license and your intended use is not permitted by statutory regulation or exceeds the permitted use, you will need to obtain permission directly from the copyright holder.

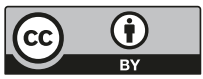

